\title{
PEMERIKSAAN BSN, BS2JPP DAN GLUKOSA URIN UNTUK MEMBANTU MENEGAKKAN DIAGNOSIS PENYAKIT DIABETES MELITUS
}

\author{
Ni Luh Gede Leni Pramesti \\ Universitas Pendidikan Ganesha \\ Singaraja, Indonesia \\ e-mail: Ipramestigd@gmail.com
}

\begin{abstract}
Abstrak
Penelitian ini bertujuan untuk mengetahui (1) Cara mendiagnosis penyakit diabetes melitus dengan melakukan pemeriksaan BSN, BS2JPP dan glukosa urin. (2) Persentase pasien patologi klinik RS Sanglah Denpasar yang positif diabetes melitus. Subjek penelitian ini adalah serum dan urin pasien yang diduga menderita diabetes melitus, sedangkan objek penelitian ini adalah kadar glukosa serum dan urin dan persentase pasien yang positif diabetes melitus. Jumlah Subjek penelitian adalah 56 serum dari 56 pasien yang diduga menderita diabetes melitus. Penelitian dilakukan di Laboratorium Patologi Klinik Rumah Sakit Sanglah Denpasar dari Tanggal 9 Mei 2005 sampai dengan 14 Mei 2005. Data dianalisis secar deskriptif. Hasil penelitian ini adalah (1) Penyakit DM didiagnosis dengan melakukan pemeriksaan BSN, BS2JPP dan glukosa urin. Kadar glukosa darah BSN dan BS2JPP pada serum diperiksa dengan alat Beckmen coulter CX7 sedangkan kadar glukosa urin diperiksa dengan menggunakan carik celup. Analisis dilakukan dengan membandingkan hasil pemeriksaan BSN, BS2JPP dan glukosa urin dengan nilai standar untuk diagnosis diabetes. Jika nilai BSN $>126$ $\mathrm{mg} / \mathrm{dL}$, BS2JPP $>200 \mathrm{mg} / \mathrm{dL}$ dan glukosa urin positif maka didignosis posiif diabetes melitus. (2) Dari 56 pasien Patologi Klinik Rumah Sakit Sanglah Denpasar yang memeriksakan kadar glukosa dan urin dari tanggal 9 - 14 Mei 2005 yang positif menderita diabetes melitus sebanyak 13 orang $(23,21 \%)$.
\end{abstract}

Kata kunci: BSN, BS2JPP, Glukosa Urin, Diabetes Melitus

\section{Pendahuluan}

Diabetes melitus merupakan penyakit metabolik yang biasanya herediter dengan tandatanda hiperglikemia dan glukosuria, sebagai akibat dari kurangnya insulin efektif dalam tubuh. Gangguan primer terletak pada metabolisme karbohidrat yang disertai juga dengan gangguan metabolisme lemak dan protein. Pada penderita diabetes melitus (DM) terjadi peningkataan kadar glukosa BSN (blood sugar nuchter) melebihi $126 \mathrm{mg} / \mathrm{dL}$ dan kadar glukosa BS2JPP (blood sugar 2 jam post prandial) melebihi $200 \mathrm{mg} / \mathrm{dL}$.

Pengidap diabetes di masyarakat kita sekarang ini mencapai 1-5\%. Artinya, dalam tiap 100 anggota masyarakat terdapat 1 sampai 5 orang pengidap diabetes. Angka ini lebih tinggi di kalangan keluarga pasien diabetes sendiri, yaitu sebanyak 20\%. Artinya, dalam 100 anggota keluarga pasien diabetes, ada 20 orang pengidap diabetes. Penyakit diabetes merupakan faktor resiko serangan jantung dan stroke. Seorang pasien diabetes mempunyai resiko terkena stroke 2-3 kali lebih besar daripada orang yang tidak mengidap diabetes. Selain itu menurut dr. Emiati, seorang pasien diabetes yang terkena serangan jantung, perjalanan penyakitnya akan menjadi lebih berat. Sayangnya lebih dari $50 \%$ kasus diabetes yang tidak diketahui oleh pasien itu sendiri. Biasanya pendeita baru memeriksakan kesehatannya bila sudah terdapat komplikasi yang tentunya lebih sulit diatasi (Suparto, 1997).

Berdasarkan Laporan Tahunan yang didapat dari catatan rekam medik Rumah Sakit Sanglah Denpasar dari tahun ke tahun menunjukkan peningkatan penderita diabetes melitus yang sangat berani. Pada 2001 pasien rawat inap yang menderita diabetes melitus sebanyak 246 orang, terdiri dari laki-laki 151 orang dan perempuan 95 orang, dari 246 penderita diabetes melitus yang keluar dalam keadaan sehat 232 orang dan yang meninggal dunia sebanyak 14 orang, sedangkan untuk pasien rawat jalan ditemukan jumlah kasus baru sebanyak 503 orang dengan jumlah kunjungan sebanyak 4762 orang. Tahun 2002 untuk pasien rawat inap terdapat 325 orang penderita diabetes melitus, yang terdiri dari 177 orang laki-laki, 148 orang 
perempuan, dari 325 penderita diabetes melitus yang keluar dalam keadaan sehat sebanyak 311 orang dan yang meninggal dunia sebanyak 14 orang, sedangkan untuk pasien rawat jalan ditemukan jumlah kasus baru sebanyak 929 orang dengan jumlah kunjungan 5424 orang. Tahun 2003 untuk pasien rawat inap yang menderita diabetes melitus sebanyak 527 orang, yang terdiri- dari laki-laki 310 orang dan perempuan 217 orang, dari 527 orang penderita diabetes melitus yang keluar dalam keadaan sehat sebanyak 496 orang, dan yang meninggal dunia sebanyak 31 orang, sedangkan untuk pasien rawat jalan ditemukan jumlah kasus baru sebanyak 608 orang dengan jumlah kunjungan 6507 orang.

Data di atas menunjukkan bahwa jumlah penderita diabetes melitus terus meningkat dari tahun ke tahun. Sampai saat ini penyakit diabetes belum bisa disembuhkan. Tujuan pengobatan hanyalah menekan kadar gula darah senormal mungkin sehingga penderita dapat menjalankan aktivitas sehari-hari seperti orang sehat serta bebas dari komplikasi-komplikasi yang dapat timbul akibat diabetes yang tidak terkendali. Berdasarkan hal tersebut diatas, maka penyakit diabetes melitus (DM) sangat perlu untuk ditanggulangi dengan mendeteksi sejak dini keberadaan penyakit ini. Penegakan diagnosis penyakit diabetes melitus (DM) dapat dilakukan dengan berbagai cara diantaranya dengan melakukan pemeriksaan kadar glukosa darah dan urin. Pemeriksaan ini merupakan pemeriksaan yang paling efisien, mudah, murah, bersifat spesifik dan cukup sensitif.

Mengingat pentingnya pemeriksaan penyakit diabetes melitus (DM) maka penulis mengambil penelitian dengan judul "Pemeriksaan BSN, BS2JPP dan Glukosa Urin untuk membantu menegakkan diagnosis penyakit diabetes melitus (DM)".

\section{Metode}

Penelitian ini merupakan penelitian deskriptif untuk menggambarkan atau mendeskripsikan cara mendiagnosis penyakit diabetes melitus (DM) dengan melakukan pemeriksaan BSN, BS2JPP dan Glukosa Urin, dan persentase jumlah pasien Patologi Klinik Rumah Sakit Sanglah Denpasar yang positif menderita diabetes melitus (DM).

Subjek penelitian ini adalah serum dan urin pasien yang diduga menderita diabetes melitus, sedangkan objek dari penelitian ini adalah (1) Kadar glukosa serum dan urin, (2) Persentase jumlah pasien yang positif menderita Diabetes Melitus. Penelitian ini dilakukan pada Sub Laboratorium Kimia Klinik Laboratorium Patologi Klinik Rumah Sakit Sanglah Denpasar dari tanggal 9 Mei sampai dengan 14 Mei 2005.

Alat yang digunakan dalam penelitian mi adalah sebagai berikut: alat Beckmen Caulter CX7, sampel Cup, Sektor khusus alat Beckmen Coulter CX7 dan tabung tempat urin. Bahan yang disiapkan adalah sebagai berikut: Serum dan urin pasien yang menjadi subjek penelitian, Reagen 1 Buffer/ATP/NADP (TRIS (hydroxymetyl)-aminomethane buffer $100 \mathrm{mmol} / \mathrm{L} ; \mathrm{pH}$ 7,8; $\mathrm{Mg}^{2 \mathrm{~T}}: 4 \mathrm{mmol} / \mathrm{L}$; ATP > 1,7 mmol/L, Reagen $2 \mathrm{HK} / \mathrm{G}-6$-PDH HEPES buffer $(30 \mathrm{mmol} \mathrm{L}: \mathrm{pH} 7,0$; $\mathrm{Mg}^{2+}: 4 \mathrm{mmol} / \mathrm{L} ; \mathrm{HK}>8,3 \mathrm{U} / \mathrm{mL}$ (yeart); G-6-PDH > $15 \mathrm{U} / \mathrm{mL}$ (E. coli); presevative. Serum kontrol untuk glukosa, Multikalibrator dan Stik reduksi urin. berikut:

Tahap-tahap pengumpulan data yang dilakukan dalam penelitian ini adalah sebagai

\section{A. Tahap Persiapan}

Pada tahap ini dilakukan persiapan instrumen dan persiapan pasien yaitu pasien yang diduga menderita penyakit diabetes melitus untuk pemeriksaan kadar glukosa darah BSN, BS2JPP dan glukosa urin.

\section{B. Tahap Pelaksanaan}

Pada tahap pelaksanaan ini dilakukan pengumpulan data kadar glukosa darah pada serum yang menjadi subjek penelitian. Pengukuran ini terdiri dari beberapa tahap yaitu terdiri dari tahap pra analitik dan tahap anal itik.

\section{1) Tahap Preparasi Sampel (Tahap Pra Analitik)}

Pada tahap ini dilakukan persiapan serum dan urin yang akan diperiksa. Serum dan urin yang digunakan dalam penelitian ini berasal dari sublaboratorium Sampling dan Prosesing Laboratorium Patologi Klinik Rumah Sakit Sanglah Denpasar. Sampel darah dan urin pasien diambil di sublaboratorium Sampling Laboratorium Patologi Klinik Rumah Sakit Sanglah Denpasar dengan ketentuan sebagai berikut. 
Untuk sampel darah puasa (BSN): 1) L Pasien dipuasakan 8-12 jam sebelum tes, 2) Tidak mendapatkan obat yang mempengaruhi kadar glukosa darah dalam serum, 3) Waktu pengambilan sampel darah pasien dalam posisi duduk yang sudah dilakukan selama minimal 5 menit, 4) Pada saat pengambilan darah pemasangan tomiquet tidak lebih dari 1 menit, 5) Darah disentrifuge hingga menjadi serum dan ditempatkan pada sampel cup yang telah diberi kode

Untuk sampel darah post prandial (BS2JPP): 1) Darah diambil setelah 2 jam tes glukosa darah puasa atau 2 jam setalah pasien makan, 2) Pasien dianjurkan mengkonsumsi makanan yang mengandung 100 gram karbohidrat sebelum tes dilakukan, 3) Waktu pengambilan sampel darah pasien dalam posisi duduk yang sudah dilakukan selama minimal 5 menit, 4) Pada saat pengambilan darah pemasangan tomiquet tidak lebih dari 1 menit, 5) Darah disentrifuge hingga menjadi serum dan ditempatkan pada sampel cup yang telah diberi kode

Untuk sampel urin: 1) Urin diambil setelah 2 jam tes glukosa darah puasa atau 2 jam setelah pasien makan, 2) Pasien dianjurkan mengkonsumsi makanan yang mengandung 100 gram karbohidrat sebelum tes dilakukan, 3) Urin yang akan diperiksa ditampung dalam tabung steril yang selanjutnya siap untuk diperiksa.

2) Tahap Pemeriksaan Serum dan Urin (Tahap Analitik)

Pada tahap analitik dilakukan pengukuran kadar glukosa darah dalam serum dengan alat Beckmen Coulter $C X 7$ dan pengukuran kadar reduksi glukosa urin. dengan menggunakan stik reduksi urin. Sebelum digunakan untuk memeriksa serum, terlebih dahulu dilakukan kalibrasi dan kontrol pada alat Beckmen Coulter CX7. Pemeriksaan dengan alat ini dilakkan secara autoanalyser.

Untuk mengetahui kadar glukosa urin dalam urin dapat dilakukan dengan cara sebagai berikut: 1) $5 \mathrm{~mL}$ urin dimasukkan kedalam tabung, 2) Stik reduksi urin dimasukkan kedalam tabung yang berisi sampel urin, didiamkan kurang lebih selama 60 detik, 3) Setelah kurang lebih 60 detik stik reduksi urin diangkat dan ditiriskan, 4) Warna stik dibandingkan dengan warna standar yang ada pada label.

Data yang diperoleh dalam penelitian ini berupa data kadar glukosa darah pada serum dan urin. Dimana data ini akan dianalisis secara deskriptif yaitu dengan membandingkan kadar BSN dan BS2JPP pada kadar glukosa plasma dan glukosa urin pada urin. Untuk mengetahui besamya persentase penderita diabetes melitus (DM) di bagian Patologi Klinik Rumah Sakit Sanglah Denpasar dihitung dengan menggunakan persamaan 1.

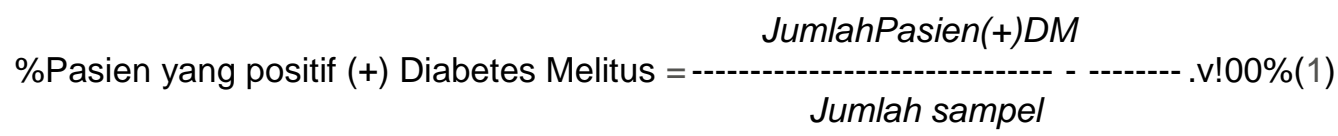

\section{Hasil dan Pembahasan}

Data yang diperoleh dengan melakukan pemeriksaan kadar glukosa BSN, BS2JPP dengan menggunakan alat Beckmen Caulter $C X 7$ dan kadar glukosa urin dengan carik celup. Kadar glukosa hasil pemeriksaan kemudian dibandingkan dengan nilai patokan yang dipakai dalam mendiagnosis penyakit diabetes melitus. Jika kadar glukosa darah BSN >126 mg/dL, kadar glukosa

darah BS2JPP > $200 \mathrm{mg} / \mathrm{dL}$, dan kadar glukosa urin positif. Hasil analisis data dapat disajikan seperti pada Tabel 1.

Tabel 1. Data Hasil Diagnosis Penyakit Diabetes Melitus

\begin{tabular}{ccccc}
\hline No & Kadar BSN & Kadar BS2JPP & Keterangan & Jumlah Pasien \\
\hline 1. & $>126 \mathrm{mg} / \mathrm{dL}$ & $>200 \mathrm{mg} / \mathrm{dL}$ & DM & 13 orang \\
2. & $>126 \mathrm{mg} / \mathrm{dL}$ & $<200 \mathrm{mg} / \mathrm{dL}$ & Belum pasti DM & 4 orang \\
3. & $<126 \mathrm{mg} / \mathrm{dL}$ & $<200 \mathrm{mg} / \mathrm{dL}$ & Bukan DM & 39 orang \\
\hline
\end{tabular}

Selanjutnya persentase pasien yang positif menderita diabetes mellitus dihitung dengan persamaan (1) dan diperoleh hasil sebesar 23,21\%.

Meningkatnya kadar glukosa dalam darah dan urin dapat diketahui dengan melakukan pemeriksaan kadar glukosa darah BSN, BS2JPP dan glukosa urin. Pada pemeriksaan ini menggunakan sampel berupa darah dan urin, karena glukosa dapat dideteksi dalam darah dan 
urin. Kadar glukosa darah BSN, BS2JPP diperiksa dengan alat Beckmen Caulter CX7 dengan menggunakan metode enzimatik. Pemeriksaan ini pada prinsipnya mengkatalisis fosforilase glukosa menjadi quinonimine. Quinonimine ini merupakan kompleks yang berwarna merah, dengan reaksi seperti dibawah ini: Glukosa + ' $\mathrm{A} \mathrm{O}_{2}+2 \mathrm{H}_{2} \mathrm{O} \quad>$ gkkonat $+\mathrm{H}_{2} \mathrm{O}_{2}$

$2 \mathrm{H}_{2} \mathrm{O}_{2}+4$ - aminantipyrine + Phenol - ${ }^{\text {pefOXldas }<:}$, quinonimine $+4 \mathrm{H}_{2} \mathrm{O}$ Pemeriksaan kadar glukosa urin menggunakan metode enzimatik dengan carik celup yang pada prinsipnya akan terjadi reaksi perubahan warna pada kertas carik celup dengan bantuan enzim glucose oksidase dan peroksidase. Dari hasil pemeriksaan didapat hasil glukosa darah BSN, BS2JPP berupa kadar dalam $\mathrm{mg} / \mathrm{dL}$ dan untuk glukosa urin positif atau negatif.

Diagnosis penyakit diabetes melitus dapat dilakukan dengan membandingkan kadar glukosa darah BSN, BS2JPP dan glukosa urin pasien dengan nilai standar yang ditetapkan oleh Perkumpulan Endokrinologi Indonesia (PERKENI). Dari data hasil penelitian kadar glukosa dapat didiagnosis jumlah pasien yang positif menderita diabetes melitus sebanyak 13 orang, sedangkan yang bukan diabetes melitus sebanyak 39 orang dan pasien yang belum pasti menderita diabetes melitus sebanyak 4 orang. Hal ini disebabkan karena kadar glukosa darah BSNS $126 \mathrm{mg} / \mathrm{dL}$, BS2JPP S $200 \mathrm{mg} / \mathrm{dL}$ dan glukosa urin positif untuk menentukan pasien yang positif diabetes melitus (DM), sedangkan pasien yang bukan diabetes melitus kadar glukosa darah BSN $<126 \mathrm{mg} / \mathrm{dL}$, kadar glukosa darah BS2JPP $<200 \mathrm{mg} / \mathrm{dL}$ dan glukosa urin negatif. Dari hasil diagnosis diketahui 4 orang yang belum pasti menderita diabetes melitus. Hal ini disebabkan karena salah satu dari hasil pemeriksaan darah meragukan (tidak sesuai dengan nilai patokan) yaitu kadar glukosa darah S $126 \mathrm{mg} / \mathrm{dL}$, BS2JPP < $200 \mathrm{mg} / \mathrm{dL}$ dan glukosa urin positif, sehingga perlu dilakukan pemeriksaan TTGO (tes toleransi glukosa oral) untuk memastikah apakah pasien tersebut menderita diabetes melitus atau tidak.

Dari data hasil diagnosis kadar glukosa darah BSN, BS2JPP dan glukosa urin diketahui bahwa dari 56 pasien yang memeriksakan kadar glukosa darah BSN, BS2JPP dan glukosa urin di Laboratorium Patologi Klinik Rumah Sakit Sanglah Denpasar dari tanggal 9-14 Mei 2005 yang didiagnosis diabetes melitus sebanyak 13 pasien, yang didiagnosis bukan diabetes melitus sebanyak 39 pasien dan yang didiagnosis belum pasti diabetes melitus sebanyak 4 pasien. Dari data tersebut maka dapat diketahui persentase jumlah pasien yang positif diabetes melitus sebanyak $23,21 \%$. Hal ini menunjukkan bahwa penderita diabetes melitus (DM) pada Rumah Sakit Sanglah Denpasar dapat dikatakan cukup tinggi jika dibandingkan dengan penderita diabetes melitus pada tahun- tahun sebelumnya.

\section{Simpulan dan Saran}

Beberapa simpulan yang dapat dikemukaakan dari hasil penelitian mi adalah: penyakit diabetes melitus (DM) didiagnosis dengan melakukan pemeriksaan kadar glukosa darah puasa (BSN), glukosa darah 2 jam setelah makan (BS2JPP) dan kadar Glukosa Urin. Kadar glukosa darah BSN, BS2JPP diperiksa dengan alat Beckmen Caulter CX7 dengan metode enzimatik. Kadar glukosa urin ditentukan dengan metode enzimatik dengan carik celup. Kadar glukosa darah dan urin dibandingkan dengan nilai kadar glukosa darah yang dipakai sebagai patokan. Jika kadar glukosa darah BSN > $126 \mathrm{mg} / \mathrm{dL}$, kadar glukosa darah BS2JPP > $200 \mathrm{mg} / \mathrm{dL}$ dan glukosa urin positif maka dapat didiagnosis menderita diabetes melitus. Dan dari 56 pasien yang diduga menderita diabetes melitus yang memeriksakan diri dari tanggal 9-14 Mei 2005 di Laboratoriuum Patologi Klinik Rumah Sakit Sanglah Denpasar yang positif menderita diabetes melitus adalah 13 orang $(23,21 \%)$.

Adapun saran-saran yang ingin disampaikan penulis terkait dengan penelitian ini adalah sebagai berikut: (1) Bagi orang yang keluarganya mempunyai riwayat penyakit diabetes melitus (DM) agar sejak dini memeriksakan diri untuk mendeteksi kandungan glukosa darahnya. (2) Perlu diadakan penyuluhan-penyuluhan kepada masyarakat mengenai pentingnya melakukan deteksi dini terhadap penyakit diabetes melitus (DM). Dilakukan penelitian serupa dengan metode yang lebih baik agar penelitian ini dapat di generalisasi.

\section{Daftar Pustaka}

Baron, D. N. Patologi Klinik Edisi 4. Teijemahan Petrus Andrianto dan Johanes Gunawan. A Short Text Book of Chemical Pathology. Jakarta : EGC

Corwin E.J. 2000. Patofisiologi. Jakarta: Buku Kedokteran EGC 
Hardjoeno. H, dkk. 2001. Interpretasi Hasil Tes Laboratorium Diagnostik.

Makasar. Lembaga Penerbitan Universitas Hasanudin

Instalasi Laboratorium Patologi Klinik Rumah Sakit Sanglah Denpasar. 2004. SOP Kimia Klinik . Denpasar.

Mansjoer Arif, dkk. 1999. Kapita Selekta Kedokteran. Jakarta: Media Aesculapius Fakultas Kedokteran Universitas Indonesia

Nala Ngurah. 1991. Usada Kencing Manis. Upada Sastra Denpasar.

Sutanegara. Dwi N dan Suastika Ketut. 1994. Pedoman Diagnosis dan Terapi Penyakit Dalam Rumah Sakit Umum Pusat Denpasar. Lab/ SMF Penyakit Dalam Fakultas Kedokteraan Universitas Udayana. Denpasar

Sjaifoellah H. M. 1996. Buku Ajar IImu Penyakit Dalam. Jilid I. Edisi 3. Jakarta.: Balai Penerbit FKUL

Suparto. H. 1997. Sehat Menjelang Usia Senja. Bandung: PT Remaja Rosdakarya

Sylvia, A Price. 1995. Patofisiologi Edisi 4. Jakarta : EGC 